\title{
PENGAPLIKASIAN MODEL PEMBELAJARAN MAKE A MATCH DALAM MENINGKATKAN KOMPETENSI SISWA PADA MATA PELAJARAN PPKn MATERI MAKNA ALINEA PEMBUKAAN UUD 1945 KELAS IX.C SMP NEGERI 10 SURABAYA SEMESTER 1 TAHUN PELAJARAN 2018/2019
}

\author{
SARWIYANTO \\ SMP Negeri 10 Surabaya \\ Email:sarwiyanto7@gmail.com
}

\begin{abstract}
ABSTRAK
Didalam aktifitas belajar mengajar, terdapat beberapa masalah yang mempengaruhi capaian kompetensi siswa didalam pembelajaran PPKn, seperti kurangnya konsentrasi siswa saat proses belajar mengajar, pasifnya partisipasi siswa, dan juga kurangnya kesadaran siswa akan pentingnya belajar PPKn. Oleh karena itu dibutuhkan kreatifitas seorang guru dalam menyusun dan menerapkan model pembelajaran yang mampu menarik siswa dalam belajar. Salah satu metode yaitu Make A Match yang menggunakan kartu berisikan pertanyaan dan jawaban. Penelitian ini menggunakan metode penilitian tindakan kelas yang menerapkan model pembelajaran Make A Match dikelas IX C SMP Negeri 10 Surabaya tahun pelajaran 2018/2019. Hasil dari penelitian ini menunjukkan bahwa pada siklus II, kompetensi pengetahuan siswa memperoleh rata-rata 85,5 yang melampaui batas indikator yaitu 78. Rata-rata skor pada kompetensi sikap siswa pada siklus II menunjukkan peningkatan sampai 3,4. Rata-rata skor pada kompetensi keterampilan siswa meningkat sampai 89,1. Dari hasil data siklus II menunjukkan penerapan dari model pembelajaran Make A Match sangat efektif dalam meningkatkan kompetensi siswa pada pembelajaran PPKn.
\end{abstract}

Kata Kunci: Kompetensi Siswa, Model Pembelajaran, Make A Match.

\section{PENDAHULUAN}

Pembelajaran dari mata pelajaran Pendidikan Pancasila dan Kewarganegaraan (PPKn) adalah salah satu pembelajaran yang memiliki tujuan dalam membentuk pribadi peserta didik untuk selalu cinta tanah air serta memiliki jiwa berbangsa dan bernegara. Pada mata pelajaran PPKn diharapkan bisa menjadi tempat edukatif dalam memberikan edukasi tentang cinta tanah air dan memberi pemahaman tentang nilai-nilai dari pancasila. Mata pelajaran PPKn akan memberikan bekal dalam mengembangkan kompetensi dasar siswa dijenjang pendidikan dasar maupun menengah di semua area kewarganegaraan yaitu kompetensi sikap, ketrampilan dan juga pengetahuan. Dengan memberikan bekal kewarganegaraan, siswa akan terbentuk menjadi warga negara Indonesia 
yang memiliki kecerdasan dan juga sikap serta berperilaku yang baik dan bertanggung jawab. Supaya tujuan dalam mencapai kompetensi belajar terpenuhi, kegiatan belajar mengajar pada pelajaran PPKn perlu menggunakan metode atau model pembelajaran yang terpusat pada peserta didik atau biasa disebut student center, dimana kreativitas pada siswa akan berkembang, membuat situasi dan kondisi pembelajaran menjadi menyenangkan agar memberikan pengalaman belajar yang beragam. Dengan begitu peserta ddik akan terbiasa lebih mandiri dalam menyelesaikan sebuah permasalahan dalam kewarganegaraan saat berada disebuah situasi.

Di suatu situasi pada peserta didik kelas IX.C di SMP Negeri 10 Surabaya memperlihatkan bahwa peserta didik belum mencapai kompetensi yang sudah di targetkan dimana nilai peserta didik pada pelajaran PPKn rata rata hanya mencapai 67, masih belum menyentuh dari nilai KKM sebesar 78. Menurut hasil observasi peserta didik kelas IX SMP Negeri 10 Surabaya ditemukan beberapa permasalahan saat proses pembelajaran seperti siswa kurang memperhatikan pembelajaran, kurangnya keterlibatan siswa selama proses pembelajaran (pasif) dan juga kurangnya kesadaran siswa akan pentingnya mata pelalajaran PPKn.

Situasi tersebut memperlihatkan bahwa terjadi permasalahan yang mempengaruhi tidak tercapainya kompetensi peserta didik dalam pembelajaran PPKn dikelas. Kurangnya konsentrasi peserta didik pada saat proses pembelajaran, pasifnya peserta didik dalam mengikuti pembelajaran, serta kesadaran peserta didik akan pentingnya mata pelajaran PPKn akan berdampak pada minat siswa dalam pembelajaran PPKn. Kondisi ini juga menunjukkan bahwa penerapan kurikulum 2013 yang belum optimal, dimana pada kurikulum 2013 menekankan pada aktifitas peserta didik dan mengurangi proporsi penjelasan dari guru, sehingga akan melatih peserta didik untuk lebih aktif didalam kelas. Namun kenyataan dilapangan bertolak belakang dengan apa yang ditargetkan.

Kurang aktifnya peserta didik dalam kegiatan pembelajaran memiliki tiga faktor yang memiliki dampak. Pertama, peserta didik tidak memiliki keberanian dalam mengutarakaan pendapatnya ke teman sekelas. Kedua, peserta didik kurang menguasai dalam menyusun gagasannya sendiri. dan ketiga, peserta didik masih tidak terbiasa saat ingin menyampaikan pendapat dengan teman sekelas. Sehingga kondisi ini mempengarugi rendahnya kompetensi siswa. Dari berbagai masalah pembelajaran PPKn yang ditemukan dikelas, diperlukanya kreatifitas guru dalam menyusun dan menerapkan model pembelajaraan yang menyenangkan dan menarik minat peserta didik supaya proses pembelajaran menjadi tidak membosankan. Model pembelajaran yang disusun dan dikembangkan diharuskan sesuai dengan karakteristik dari mata pelajaran PPKn secara keseluruhan dalam meningkatkan kualitas belajar peserta didik. Metode pembelajaran juga diharuskan lebih ke pendekatan dalam mengembangkan karakter peserta didik yang menjadikan mereka warga negara yang cerdas dan 
cinta dengan tanah air secara sepenuhnya didalam proses pembelajaran yang autentik.

Didalam integrasi kompetensi sikap, pengetahuan, dan keterampilan. Selain itu model pembelajaran yang mengarahkan peserta didik bersikap dan berpikir ilmiah (scientifc), dimana model pembelajaran ini mendorong peserta didik untuk berfikir kritis dalam menyelesaikan masalah. Salah satu model pembelajaran yang mengikutsertakan peserta didik untuk aktif selama proses pembelajaran adalah model pembelajaran kooperatif, yang mana pembelajaran kooperatif (cooperative learning) adalah suatu bentuk pembelajaran menerapkan kegiatan berkelompok dan bekerjasama dengan siswa lain dikelas (Rusman, 2014: 202). Didalam proses pembelajaran kooperatif melatih peserta didik untuk saling bekerjasama didalam kelompok. Selain dapat meningkatkan kemampuan kognitif, peserta didik dapat belajar dalam mengungkapkan pendapat dan juga menghargai pendapat orang lain selama berdiskusi dengan teman sekelompok.

Didalam model belajar kooperatif, terdapat beberapa metode yang dapat diterapkan, yaitu jigsaw, make a match, dan lain sebagainya. Metode atau model pembelajaran make a match merupakan salah satu pembelajaran kooperatif yang dikembangkan Lorna Curran (dalam Rusman, 2014: 206). Pembelajaran kooperatif yang menggunakan metode make a match dengan memanfaatkan media berupa kartu yang berisikan soal/jawaban dari materi yang dipelajari. Peserta didik diminta untuk mencari pasangan (soal dan jawaban) dari masingmasing kartu tersebut.

Dengan menggunakan model pembelajaran make a match, diharapkan peserta didik akan lebih berperan aktif selama proses pembelajaran yang menjadikan kompetensi belajar bisa tercapai dengan optimal. Kelebihan dari metode ini adalah peserta didik di tuntut untuk bergerak dalam menemukan pasangan soal dan jawaban. Kegiatan pembelajaran ini akan memberikan stimulus peserta didik agar berfikir kritis dalam mencari solusi, berdiskusi dan juga berpendapat.

Berdasarkan latar belakang tersebut maka perlu diadakan penelitian dengan judul: "Pengaplikasian Model prmbelajaran Make a Match dalam meningkatkan Komptensi Siswa pada mata pelajaran PPKn materi makna alinea pembukaan 1945 Kelas IX.C SMP Negeri 10 Surabaya Semester 1 Tahun pelajaran 2018/2019." Rumusan masalah pada penelitian ini adalah: bagaimanakah cara dalam meningkatkan kompetensi belajar PPKn materi Makna Alinea Pembukaan UUD 1945 dengan menggunakan model pembelajaran Make A Match pada siswa kelas IX Semester 1 Tahun Pelajaran 2018/2019? 


\section{METODE PENELITIAN}

Pada penelitian ini, peneliti menerapkan metode Penelitian Tindakan Kelas (PTK) (Classroom Action Research). Metode ini digunakan untuk pengaplikasikan metode Make A Match dalam upaya meningkatkan kompetensi belajar siswa pada mata pelajaran PPKn materi Pembukaan UUD 1945 pada peserta didik kelas IX SMP Negeri 10 Surabaya. Menurut Subyantoro (2018: 15) Langkah-langkah dalam setiap siklus terdiri dari empat langkah yaitu (1) perencanaan (planning) (2) pelaksanaan tindakan (acting) (3) pengamatan (observing) (4) refleksi (reflecting). Didalam sebuah siklus terdapat pemikiran dan refleksi dalam suatu tindakan.

Penelitian ini dilakukan di SMP Negeri 10 Surabaya. Penelitian ini dilaksanakan pada semester 1 tahun pelajaran 2018/2019 dibulan Agustus 2019 hingga bulan Oktober 2019. Subjek penelitian yang menerima tindakan adalah peserta didik kelas IXC SMP Negeri 10 Surabaya tahun pelajaran 2018/2019. Penelitian ini mengambil subjek guru mata pelajaran PPKn SMP Negeri 10 Surabaya.

Instrumen pendukung yang digunakan adalah observasi, wawancara, dokumentasi, kuisioner dan tes. Penelitian ini di analisis secara deskriptif komparatif dan teknik analisis kritis digunakan dalam penelitian ini saat menganalisis data yang diperoleh. Teknik analisis deskriptif komparatif digunakan saat membandingkan data kuantitatif dari hasil kompetensi siswa antar siklus. Pada observasi, peneliti menggunakan teknik analisis deskriptif komparatif dimana ketika menganalisis kekurangan serta kelebihan selama guru dan siswa berinteraksi.

\section{HASIL DAN PEMBAHASAN}

Guru mengalami kesulitan pada saat kegiatan pembelajaran pada mata pelajaran PPKn di kelas IX C SMP Negeri 10 Surabaya pada materi Pembukaan UUD 1945 dikarenakan kurangnya keterlibatan siswa sehingga mempengaruhi rendahnya kompetensi siswa. Pada kompetensi pengeahuan, siswa mendapatkan nilai yang masih rendah dari KKM yang sudah ditentukan. Sebanyak 90,6\% siswa dari 32 jumlah siswa yang mendapatkan kompetensi pengetahuan yang masih dibawah KKM dan hanya 9,4\% siswa yang mampu mencapai KKM. Saat kegiatan pra-siklus, kompetensi dari pengetahuan peserta didik mencapai ratarata 60,7, dimana hasil tersebut meunjukkan nilai yang lebih rendah dari KKM.

Sebanyak 53,1\% siswa mampu mencapai kompetensi keterampilan yang cukup baik, pada kompetensi keterampilan yang kurang baik sebanyak 40,6\% siswa dan hanya sebanyak $6,3 \%$ siswa yang mencapai kompetensi keterampilan yang baik. Kompetensi keterampilan siswa pada kondisi awal hanya mencapai rata-rata 55,3 (kurang baik). Pada saat proses pembelajaran, ada sekitar 65,6\% yang masih kurang aktif saat mengikuti pembelajaran, dan hanya $28,1 \%$ siswa yang andil dalam pembelajaran. 


\section{Siklus I}

Di tahap perbaikan kegiatan siklus I dilaksanakan pada hari Senin, 26 Agustus 2018, jumlah siswa yang hadir pada kelas IX C adalah 41 siswa. Langkah pembelajaran yang diterapkan adalah sebagai berikut:

1. Pada kegiatan awal guru memberi salam dan menjelaskan secara garis besar tentang materi dan kegiatan pembelajaran hari ini.

2. Setelah menjelaskan secara umum kegiatan, guru memulai menjelaskan secara singkat materi tentang Pembukaan UUD 1945.

3. Guru menjabarkan kegiatan dari model pembelajaran Make A Match.

4. Guru membagi kelas menjadi 5 kelompok kecil dan memberi waktu sekitar kurang lebih 10 menit untuk membaca dan memahami materi.

5. Guru mengacak kartu setelah itu dibagi kesemua siswa. Masing-masing siswa diberi satu buah kartu soal atau kartu jawaban. Setelah itu siswa menulis jawaban di buku masing-masing dan di beri waktu selama 2 menit.

6. Guru meminta siswa membentuk 2 barisan, yang satu pemegang kartu soal dan yang lain memegang kartu jawaban serta saling berhadapan. Pada barisan yang pemegang kartu jawaban diminta untuk memberitahukan kartu yang mereka pegang secara urut dari kanan ke kiri.

7. Guru meminta siswa untuk mencocokkan kartu jawaban dan diberi waktu selama 2 menit, jika ada yang menemukan sebelum waktu habis, siswa akan mendapatkan poin.

8. Guru meminta siswa untuk pindah ke sisi kanan guru jika yang sudah menemukan pasangan soal dan jawaban, dan yang belum masih di sisi kiri guru.

9. Guru akan memberi hukuman kepada siswa yang belum bisa menemukan dengan memberi tambahan waktu sampai siswa mampu menemukan dan mencocokkan kartu soal dan jawaban.

10. Setelah semua sudah menemukan dan mencocokkan, siswa diminta untuk menunjukkan semua kartu untuk di lihat apakah sudah cocok atau tidak cocok.

11. Setelah kagiatan Make A Match selesai, guru meminta siswa untuk mengembalikan semua kartu dan kemudian guru menyampaikan timbal balik dari kegiatan pembelajaran yang telah dilaksanakan

12. Kegiatan akhir guru melakukan kegiatan refleksi dan memberi soal evaluasi dengan jenis soal uraian yang berhubungan dengan materi pembelajaran. 


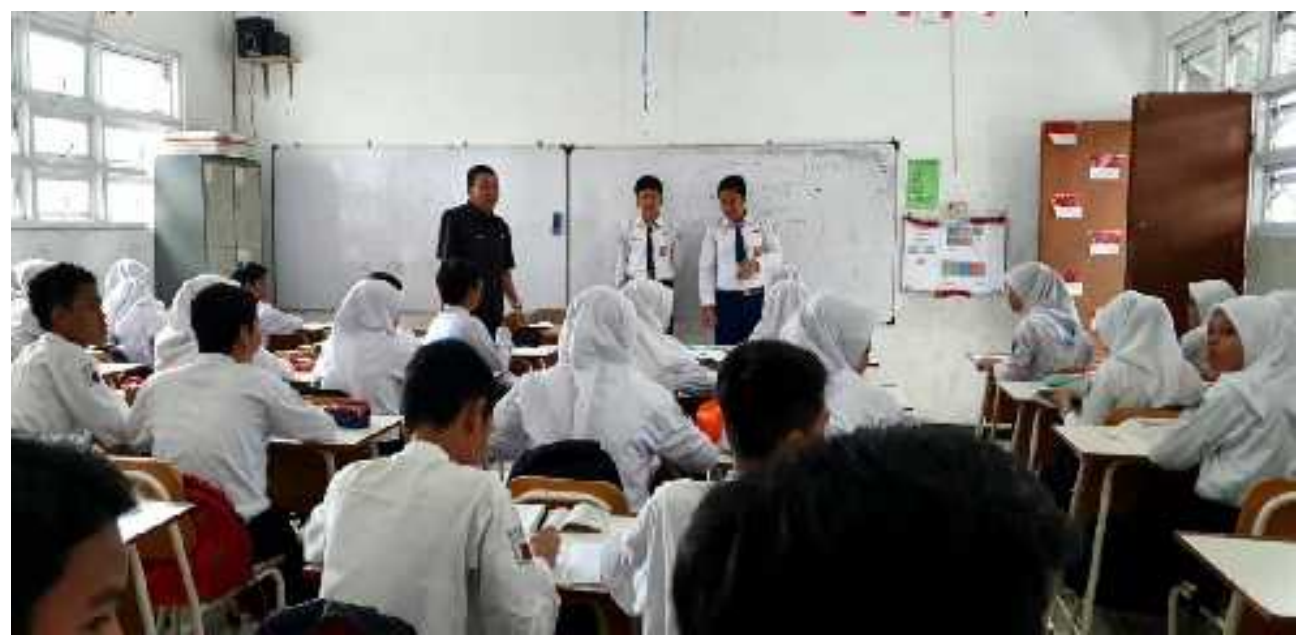

Gambar 1. kegiatan siklus 1 guru dalam pembelajaran kelas 9C SMP

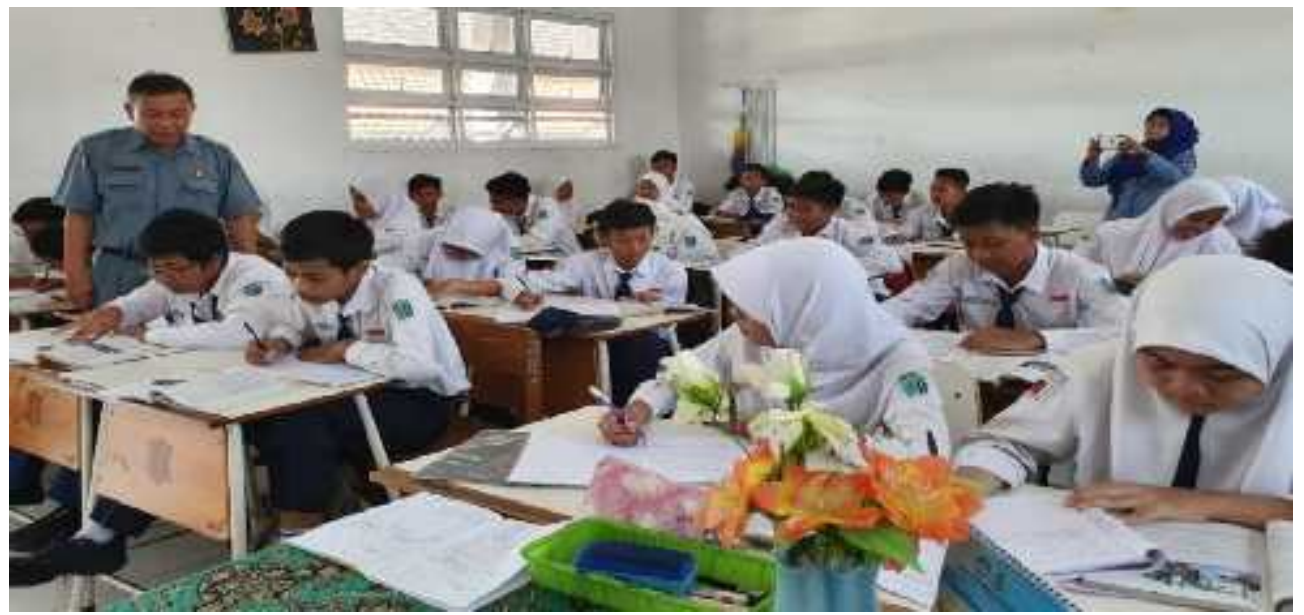

Gambar 2. Kegiatan siklus 2 guru dalam pembelajaran kelas 9C SMP Negeri

\section{Siklus II}

Pada tahap pelaksanaan tindakan kelas siklus II dilaksanakan pada hari Jumat, 7 September 2018, siswa yang mengikuti dikelas sebanyak 41 siswa. Langkah pembelajaran yang dilaksanakan adalah sebagai berikut:

1. Kegiatan awal guru memberi salam dan menjelaskan secara umum tentang materi dan kegiatan pembelajaran hari ini.

2. Pada Kegiatan inti guru menjelaskan materi pelajaran PPKN tentang Pembukaan UUD 1945 secara singkat.

3. Guru membagi kelompok menjadi 5 kelompok dengan masing masing kelompok beranggotakan 4 siswa, dan meminta siswa memahami materi UUD 1945 
4. Guru memberikan waktu selama 10 menit untuk memahami, dan jika ada siswa yang belum paham, guru meminta siswa lain untuk menjelaskan kepada siswa yang masih belum paham.

5. Setelah selesai diskusinya, guru meminta siswa untuk duduk ke bangkunya masing masing dan setelah itu membagi kelas menjadi 2 kelompok besar, 1 kelompok sebelah kanan dan 1 kelompok ada disebelah kiri

6. Guru membagi kartu ke semua siswa secara acak, setiap siswa mendapatkan 1 kartu, setelah itu guru meminta siswa untuk memikirkan jawaban dari kartu yang telah dibagi

7. Guru meminta kepada siswa untuk menemukan jawaban dari kartu yang dibawanya.

8. Guru mengecek masing masing siswa, apakah sudah menemukan kecocokan kartu, yang sudah mendapatkan kecocokan kartu, guru meminta siswa untuk menjelaskan didepan kelas.

9. Pada kegiatan siklus II ini, semua siswa mampu menemukan dan mencocokan kartu jawaban, sehingga guru hanya menonfirmasi temuan dari jawaban siswa.

10. Guru memberikan reward kepada semua siswa berupa pujian karena sudah bekerja dengan baik dalam menemukan dan mencocokkan jawaban kartu

11. Setelah kagiatan Make A Match selesai, guru memberikan timbal balik kegiatan pembelajaran

12. Kegiatan akhir guru melakukan kegiatan refleksi dan memberi soal evaluasi dengan jenis soal uraian yang berhubungan dengan materi pembelajaran.

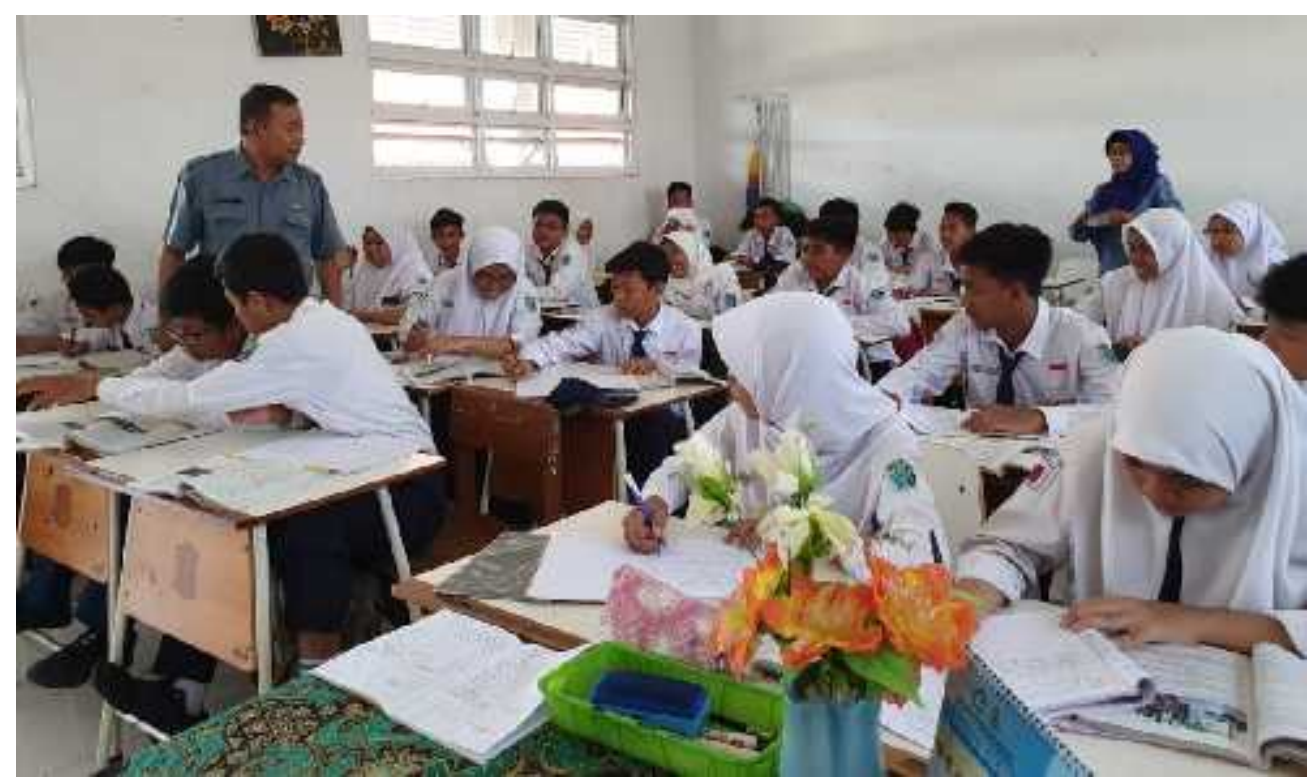

Gambar 3. Kegiatan guru dalam pembelajaran PPKn kelas 9C SMP Negeri 10 Surabaya 


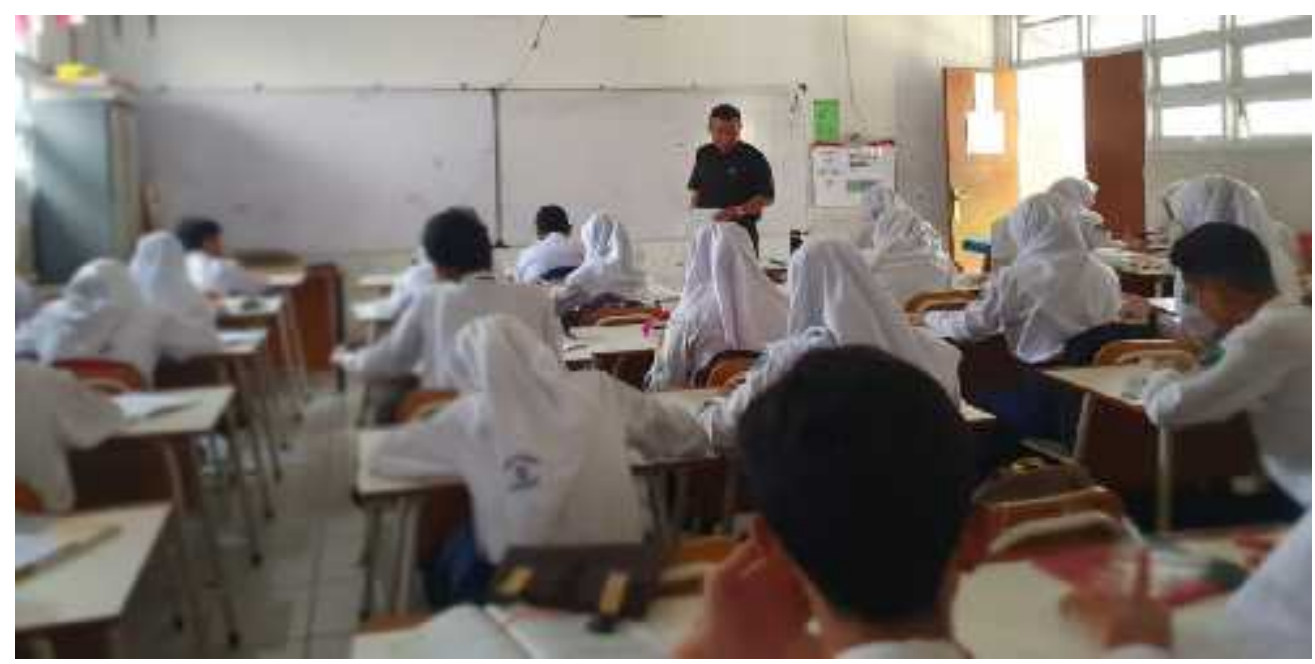

Gambar 4. Kegiatan guru dalam pembelajaran PPKn kelas 9C SMP Negeri 10 Surabaya

Hasil dari pelaksanaan kegiatan perbaikan pembelajaran PPKn pada siklus 1 dan siklus 2 dengan penerapan model pembelajaran Make A Match sebanyak, terjadi peningkatan kompetensi siswa. Data hasil penilaian kompetensi pada siswa kelas IX C SMP Negeri 10 Surabaya di jabarkan pada tabel 1 dibawah ini.

Tabel 1. Hasil Rata - Rata Nilai Kompetensi Belajar PPKn pada Siswa Kelas IX C SMP Negeri 10 Surabaya pada siklus I dan siklus II

\begin{tabular}{|c|c|r|c|}
\hline Kompetensi & Kondisi Awal & Siklus I & Siklus II \\
\hline Pengetahuan & 60,7 & 79,5 & 85,8 \\
\hline Peningkatan (\%) & - & 30,9 & 7,9 \\
\hline Sikap & 1,8 & 2,4 & 3,4 \\
\hline Peningkatan (\%) & - & 36,0 & 42,1 \\
\hline Keterampilan & 55,3 & 71,9 & 89,1 \\
\hline Peningkatan (\%) & - & 30,0 & 23,9 \\
\hline
\end{tabular}

Pada kondisi awal di kompetensi pengetahuan siswa menunjukkan hasil yang mencapai rata-rata 60,7 dan setelah itu bertambah menjadi 79,5 pada siklus I. Setelah dilakukan pembelajaran siklus II siswa mampu mencapai ratarata 85,8 , hasil ini menujukkan adanya peningkatan yang signifikan karena sudah melampaui indikator kinerja yang sudah ditetapkan sebesar 80, sehingga dikatakan bahwa pada siklus II guru sudah mencapai target yang diinginkan.

Pada kondisi awal kompetensi sikap siswa yang mencapai rata-rata 1,8 Setelah dilakukan pembelajaran siklus 1, nilai bertambah menjadi 2,4. Nilai rata-rata siswa pada siklus II meningkat kembali menjadi 3,4 (sikap aktif). 
Pada kondisi awal nilai keterampilan siswa hanya mencapai rata-rata 55,3. Setelah dilakukanya siklus I, nilai rata-rata siswa meningkat menjadi 71,9. Nilai rata-rata siswa meningkat kembali menjadi 89,1 setelah dilaksanakan pembelajaran siklus II. Hasil ini menujukkan adanya peningkatan yang signifikan dari nilai keterampilan siswa, karena sudah melampaui indikator kinerja yang sudah ditetapkan sebesar 80, sehingga dikatakan bahwa pada siklus II guru sudah mencapai target yang diinginkan pada keterampilan siswa. Dari hasil data yang diperoleh, memperlihatkan bahwa penerapan model pembelajaran Make A Match sangat efektif untuk diterapkan dalam meningkatkan kompetensi siswa pada pembelajaran PPKn.

Hasil dari pembelajaran PPKn dengan penerapan model atau metode Make A Match mampu dan berhasil dalam meningkatkan kompetensi hasil belajar siswa. Hasil dari keberhasilan ini dapat di lihat dari perubahan dan peningkatan nilai sikap, pengetahuan dan keterampilan siswa yang telah mencapai ketuntasan kriteria minilal (KKM) yaitu sebesar 78. Peningkatan nilai kompetensi siswa yang signifikan diperoleh dari kegiatan pembelajaran siklus I dan juga siklus II.

Dari hasil ke dua siklus yang telah dilakukan guru, terjadi peningkatan minat siswa untuk mengikuti pembelajaran karena model pembelajaran Make A Match yang diterapkan dianggap sangat menarik untuk siswa. Terlihat peningkatan keaktifan dan antusisasme siswa dalam berkompetisi ketika menemukan pasangan kartu soal dan kartu jawaban yang sudah disiapkan oleh guru. Dari keterlibatan siswa saat proses pembelajaran juga sangat mempengaruhi nilai hasil belajar siswa (sikap, pengetahuan dan keterampilan) yang menunjukkan perkembangan yang signifikan.

Proses perbaikan pembelajaran pada siklus I dan siklus II, siswa terlihat sangat aktif dan semangat saat mencari kecocokan kartu. Siswa juga aktif dalam berkelompok dan berdiskusi tanya jawab mengenai materi yang diberikan oleh guru, mereka saling bekerja sama untuk menemukan jawaban. Sehingga mampu mendorong siswa untuk berfikir lebih luas dan mampu medalami materi sehingga siswa betu-betul memahami materi UUD 1945 pada mata pelajaran PPKn.

Hasil dari pembelajaran yang telah diterapkan oleh peneliti sama dengan pendapat Lie (2010: 55) yang menyebutkan bahwa pembelajaran Make A Match memiliki kelebihan yaitu: mampu meningkatkan hasil belajar siswa, suasana pembelajaran menjadi menyenangkan sebab model pembelajaran tersebut seperti bermain game, mampu meningkatkan pemahan siswa dan juga memberikan motivasi siswa untuk belajar memahami materi. Dengan menerapkan model pembelajaran tersebut juga mampu meningkatkan kerjasama antar siswa. 
Meningkatnya kompetensi hasil belajar siswa juga sepaham dengan Huda (2014: 253) yang menjelaskan bahwa keunggulan dalam menerapkan pembelajaran make a match adalah mampu meningkatkan motivasi belajar siswa dimana dengan model pembelajaran tersebut dengan media kartu yang telah dikemas dengan sempurna menjadikan suasana kelas menjadi menyenangkan dan akan mendorong semangat belajar dan minat siswa untuk terlibat selama proses pembelajaran berlangsung.

\section{KESIMPULAN}

Dari hasil data penelitian yang diperoleh dapat disimpulkan bahwa penerapan model pembelajaran Make A Match mampu meningkatkan kompetensi hasil belajar siswa pada pelajaran PPKn dengan materi Pembukaan UUD 1945 pada peserta didik kelas IX C SMP Negeri 10 Surabaya Semester 1 Tahun Pelajaran 2018/2019. Setelah pelaksanaan perbaikan pembelajaran siklus II kompetensi pengetahuan siswa mampu memperoleh rata-rata skor 85,8 yang mana sudah mampu melampaui indikator kinerja yang ditetapkan sebesar 78. Nilai rata-rata siswa di kompetensi sikap pada siklus II meningkat kembali menjadi 3,4 (sikap aktif). Nilai rata-rata siswa pada kompetensi keterempilan meningkat menjadi 89,1 setelah dilakukan pembelajaran siklus II. Dari hasil data yang diperoleh pada siklus II, menunjukkan bahwa penerapan model pembelajaran Make A Match sangat efektif untuk diterapkan dalam meningkatkan kompetensi siswa pada pembelajaran PPKn.

Saran untuk guru dan juga pihak sekolah untuk disarankan menggunakan model pembelajaran Make A Match, yang mana metode ini dapat diterapkan ke semua mata pelajaran, sehingga dengan metode ini mampu membuat suasana kelas menjadi aktif dan akan lebih memotivasi siswa dalam meningkatkan hasil belajar dengan kompetensi-kompetensi pada mata pelajaran lain. Saran bagi siswa supaya selalu berandil dan aktif selama proses pembelajaran berlangsung sehingga akan menciptakan proses pembelajaran mennjadi menyenangkan dan akan mendapatkan hasil belajar yang memuaskan

\section{DAFTAR PUSTAKA}

Hamdayama, Jumanta. 2017. Metodologi Pengajaran. Jakarta: Bumi Aksara.

Huda, Miftahul. 2014. Model-Model Pengajaran dan Pembelajaran:Isu-Isu Metodis dan Paradigmatis. Yogyakarta: Pustaka Pelajar

Lie, Anita. 2010. Cooperatife Learning: Mempraktikkan Cooperative Learning di Ruang-Ruang Kelas. Jakarta: Gramedia Wisiasarana Indonesia

Mediatati, Nani dan Ardhiyanto, Ferditya. 2018. Meningkatkan Hasil Belajar Siswa Dalam Pembelajaran PKn Menggunakan Model Pembelajaran Make A 
Match di Kelas IX di SMP Negeri 7 Salatiga. Jurnal PKn Progresif, Vol. 13 No. 2 Desember 2018

Purnianingrum, Leny Shela. 2015. Peningkatan Kualitas Pembelajaran Pkn Melalui Model Make A Match Berbantuan Media Kartu Bergambar Siswa Kelas V SDN Karanganyar 02 Kota Semarang. Jurnal Jurusan Pendidikan Guru Sekolah Dasar Fakultas Ilmu Pendidikan Universitas Negeri Semarang

Rusman. 2014. Model-Model Pembelajaran, Mengembangkan Profesionalisme Guru. Depok: Rajawali Pers (Rajagrafindo Persada).

Subyantoto. 2018. Penelitian Tindakan Kelas: Metode, Kaidah Penulisan, dan Publikasi. Depok: Rajawali Pers (Rajagrafindo Persada).

Sumartini, Ai Tin dan Putra, Asep Sutisna. 2018. Pendidikan Pancasila dan Kewarganegaraan untuk SMP/MTs Kelas IX: Buku Guru. Jakarta: Kementerian Pendidikan dan Kebudayaan.

Suprijono, Agus. 2014. Cooperative Learning. Yogyakarta: Pustaka Pelajar.

Suwandi, Sarwiji. 2008. Penelitian Tindakan Kelas (PTK) dan Penulisan Karya Ilmiah. Surakarta: Panitia Sertifikasi Guru Rayon 13.

Trianto. 2008. Mendesain Pembelajaran Konstektual di Kelas. Jakarta. Cerdas Pustaka Publisher.

Yamin, Martinis. 2016. Kiat Membelajarkan Siswa. Jakarta: GP Press 